\title{
PROTEIN SYNTHESIS GAME
}

J.C.Q. Carvalho; E.M. Miranda; C.C.P. da Silva; ${ }^{*} V$. A. David; ${ }^{*}$ T. E. L. de Souza; ${ }^{*} P$. Kleine; ${ }^{*} L$. B. de Almeida; L. D. S. Abel

Centro de Biotecnologia Molecular Estrutural (CBME) - Instituto de Física de São Carlos - USP -São Carlos SP - Brasil; Centro de Divulgação Científica e Cultural (CDCC/USP) - São Carlos - SP - Brasil

The theoretical explanation of biological concepts, associated with the use of teaching games and models, intensify the comprehension and increase students interest, stimulating them to participate actively on the teaching-learning process. The staff of dissemination from Centro de Biotecnologia Molecular Estrutural (CBME), in partnership with the Centro de Divulgação Científica e Cultural (CDCC), presents, in this work, a new educational resource denoted: Protein Synthesis Game. The approach of the game involves the cytological aspects of protein synthesis, directed to high school students. Students are presented to day-by-day facts related to the function of a given protein in the human body. Such task leads players to the goal of solving out a problem through synthesizing a specified protein. The game comprises: (1) a board illustrated with the transversal section of animal cell, with its main structures and organelles and sequences of hypothetical genes; (2) cards with the description of steps and other structures required for protein synthesis in eukaryotic cells; (3) pieces representing nucleotides, polynucleotides, ribosome, amino acids, and polypeptide chains. In order to play the game, students take cards that sequentially permit them to acquire the necessary pieces for production of the protein described in each objective. Players must move the pieces on the board and simulate the steps of protein synthesis. The dynamic of the game allows students to easily comprehend processes of transcription and translation. This game was presented to different groups of high school teachers and students. Their judgments have been heard and indicated points to be improved, which helped us with the game development. Furthermore, the opinions colleted were always favorable for the application of this game as a teaching resource in classrooms. Financial support: FAPESP/CEPID and $\mathrm{CNPq}$ 